\title{
The effect of phosphate and carbonate-bicarbonate supplements on the rumen buffering systems of sheep
}

\author{
By BIJAN EMMANUEL,* M. J. LAWLOR ANd D. McALEESE† \\ Animal Nutrition and Biochemistry Department, The Agricultural Institute, \\ Dunsinea, Castleknock, Co. Dublin, Ireland
}

(Received 3 October 1969-Accepted 2 March 1970)

\begin{abstract}
I. Two wethers fitted with permanent rumen cannulas were used to study the effect of two mineral supplements, $\mathrm{Na}_{2} \mathrm{HPO}_{4}$ and a 1 : I mixture of $\mathrm{Na}_{2} \mathrm{CO}_{3}$ and $\mathrm{NaHCO}_{3}$, on the buffering system in the rumen of sheep given a pelleted roughage-concentrate diet.

2. Measurements were made of rumen $\mathrm{pH}$, buffering capacity value $(\beta)$, total volatile fatty acids (VFA), $\mathrm{CO}_{2}$ and inorganic phosphorus concentrations as well as rumen cellulase activity.

3. The addition of either mineral supplement to the diet significantly $(P<0.001)$ increased the rumen $\mathrm{pH}$ values during the critical post-feeding period, there was a difference of only $0.5 \mathrm{pH}$ unit between the minimum and maximum $\mathrm{pH}$ values.

4. Both mineral supplements significantly increased the concentrations of $\mathrm{CO}_{2}$ in the rumen fluid and rumen cellulase activity. They resulted in a general reduction in total VFA concentrations. It is suggested that this may possibly arise from increased absorption of VFA associated with increased $\mathrm{CO}_{2}$ tension in the rumen fluid.

5. The $\mathrm{Na}_{2} \mathrm{HPO}_{4}$ supplement significantly $(P<0.001)$ increased the $\beta$ values in the $\mathrm{pH}$ range $6-8$, whereas the bicarbonate supplement contributed to raising the $\beta$ values in the $\mathrm{pH}$ range $5-6$.

6. The bicarbonate supplements raised cellulose digestibility from $39.7 \%$ for the control diet to $45.6 \%$ and the addition of $\mathrm{Na}_{2} \mathrm{HPO}_{4}$ further raised the digestibility to $5 \mathrm{I} \cdot \mathrm{I} \%$. It would appear that low rumen $\mathrm{pH}$ impairs rumen cellulase activity and this could be offset by the addition of mineral supplements.
\end{abstract}

The feeding of pelleted roughage-concentrate diets to ruminants has been shown to result in a marked decrease in both the rate of salivary secretion and the time which animals spend ruminating (Balch \& Rowland, 1957; Reid, Hogan \& Briggs, 1957; Lawlor, Giesecke \& Walser-Kärst, 1966). Many attempts have been made to compensate for this reduction in salivary secretion and the consequent reduction in the buffering capacity of the rumen by the addition of supplementary buffers to the diet (Nicholson \& Cunningham, I96r; Nicholson, Loosli \& Warner, I960; Nicholson, Cunningham \& Friend, I962, 1963; Lassiter \& Cook, 1961, 1963; Lassiter, Cullison \& Warren, 1962; Oltjen, Sirny \& Tillman, 1962; Raun, Burroughs \& Woods, 1962). The results obtained by these workers are somewhat inconclusive and were primarily based on measurements of animal performance. Emmanuel, Lawlor \& McAleese (1969) have recently studied the buffering properties of the rumen fluid from sheep given a pelleted roughage-concentrate diet. They found that the volatile fatty acids (VFA) were the most important buffer component at the prevailing $\mathrm{pH}$ in the rumen and the bicarbonate and phosphate buffering systems did not appear to be adequate or effective in regulating the rumen $\mathrm{pH}$. This probably reflects low levels of salivary

* Present address: University of Alberta, Edmonton, Alberta, Canada.

† Present address: Agricultural Chemistry Department, University College, Dublin. 
secretion under such dietary regimens. The present work was undertaken to study the effect of supplementation with mineral buffers on the rumen $\mathrm{pH}$ and buffering capacity, VFA, total $\mathrm{CO}_{2}$ and inorganic phosphorus concentrations as well as cellulase activity in the rumen of sheep given a pelleted roughage-concentrate diet.

\section{EXPERIMENTAL}

Animals and diets. Two Suffolk cross-bred wethers fitted with permanent rumen cannulas were used. The sheep were housed in individual pens containing slatted wooden floors. Details of the roughage-concentrate diet, which contained $45 \%$ of ground barley straw, have been given in a previous paper (Emmanuel et al. 1969). Two dietary buffers, disodium hydrogen phosphate and a $1:$ I mixture of sodium carbonate and sodium bicarbonate, were studied. Each buffer was included at a level of $3 \%$ by weight in the pelleted diet. As in the previous work, the animals were given $1000 \mathrm{~g}$ of the control diet at 08.00 hours and $500 \mathrm{~g}$ at $\mathrm{i} 7.00$ hours. For the supplemented diets these quantities were increased by $3 \%$ in order to offset the dilution effects resulting from the addition of the buffers. Both sheep were first fed on the control diet and subsequently one sheep received the diet supplemented with the phosphate buffer while the other was given the diet containing the carbonate-bicarbonate buffer. When the observations were completed the treatments were reversed and an adjustment period of 3 weeks was allowed before recommencing sampling. The sheep had free access to drinking water.

Sampling and analytical methods. The procedure used in obtaining representative samples of the rumen fluid and the chemical methods employed for analysis of rumen contents have been described by Emmanuel et al. (1969). The buffering capacity $(\beta)$ was expressed as the quantity of titrant (m-equiv./I rumen fluid) required to bring about 2 unit changes in $\mathrm{pH}$. For each titration two portions were used: ( $\mathrm{r}$ ) titrated against $0.5 \mathrm{~N}-\mathrm{HCl}$ to $\mathrm{pH}_{4}$ and (2) titrated against $0.5 \mathrm{~N}-\mathrm{NaOH}$ to $\mathrm{pH} 8$.

Cellulase activity in the rumen. The in vitro technique of Halliwell (I957) was used to measure rumen cellulase activity. The incubations were carried out at $39-40^{\circ}$ for $45 \mathrm{~h}$ in $15 \mathrm{ml}$ centrifuge tubes closed with rubber stoppers and Bunsen valves. Each tube contained $\mathrm{I} \mathrm{ml}$ of filtered rumen fluid, $7 \mathrm{ml}$ of phosphate buffer, I $\mathrm{ml}$ of urea solution and $50 \mathrm{mg}$ of dewaxed cotton fibre as substrate. The breakdown of insoluble cellulose was followed by gravimetric determination of the residual cellulose (Halliwell, 1957). The quantity of cellulose hydrolysed was calculated by difference, taking into account the cellulose content of the $1 \mathrm{ml}$ of rumen fluid used. The latter value was determined on the unincubated control samples. Cellulase activity was expressed as a percentage of the total amount of cellulose incubated which was digested. Rumen samples were obtained at 4 and $9 \mathrm{~h}$ after feeding; these intervals corresponded approximately to periods of minimum and maximum rumen $\mathrm{pH}$.

Statistical analysis. In order to test the significance of changes between treatments for the various measurements studied throughout the sampling period, quadratic time curves were fitted to the observations and the changes in these curves between treatments were subjected to statistical tests. Since the experiment involved only two sheep 
no valid estimate of animal-to-animal variation could be obtained. The sampling procedure was repeated at $3 \mathrm{~d}$ intervals for up to twelve samplings and therefore an error estimate could be based on day-to-day variation. The validity of this procedure depends on an assumption that observations on successive days can be regarded as independent. The conclusions do not necessarily apply to sheep other than those used in this experiment.

\section{RESULTS}

The results given are the mean values obtained for both sheep. The mean rumen fluid $\mathrm{pH}$ and VFA, inorganic $\mathrm{P}$ and $\mathrm{CO}_{2}$ concentrations are given in Table $\mathrm{r}$. It will be seen that whereas a marked decline in rumen $\mathrm{pH}$ occurred when the control diet was

Table I. Mean $p H$ and concentration (m-equiv./l) of volatile fatty acids $(V F A)$, inorganic phosphorus and $\mathrm{CO}_{2}$ in the rumen contents of two sheep $\mathrm{I} h$ before and at hourly intervals after feeding

\begin{tabular}{|c|c|c|c|c|c|c|c|c|c|c|c|}
\hline Measurement & Diet & $-\mathrm{I} h$ & I h & $2 \mathrm{~h}$ & $3 \mathrm{~h}$ & $4 \mathrm{~h}$ & $5 \mathrm{~h}$ & $6 \mathrm{~h}$ & $7 \mathrm{~h}$ & $8 \mathrm{~h}$ & $9 \mathrm{~h}$ \\
\hline $\mathrm{pH}$ & $\begin{array}{l}\text { Control } \\
\text { Control }+\mathrm{P} \\
\text { Control }+\mathrm{B}\end{array}$ & $\begin{array}{l}6 \cdot 45 \\
6 \cdot 46 \\
6 \cdot 57\end{array}$ & $\begin{array}{l}5.59 \\
6.06 \\
6.37\end{array}$ & $\begin{array}{l}5 \cdot 40 \\
5 \cdot 93 \\
6 \cdot 16\end{array}$ & $\begin{array}{l}5.44 \\
5.89 \\
6.06\end{array}$ & $\begin{array}{l}5 \cdot 44 \\
5 \cdot 96 \\
6 \cdot 13\end{array}$ & $\begin{array}{l}5 \cdot 63 \\
6 \cdot 00 \\
6 \cdot 17\end{array}$ & $\begin{array}{l}5 \cdot 80 \\
6 \cdot 10 \\
6 \cdot 27\end{array}$ & $\begin{array}{l}5 \cdot 92 \\
6 \cdot 15 \\
6 \cdot 30\end{array}$ & $\begin{array}{l}6 \cdot 08 \\
6 \cdot 20 \\
6 \cdot 39\end{array}$ & \\
\hline Total VFA & $\begin{array}{l}\text { Control } \\
\text { Control }+\mathrm{P} \\
\text { Control }+\mathrm{B}\end{array}$ & $\begin{array}{l}75^{\cdot} \cdot 9 \\
47 \cdot 3 \\
58 \cdot 6\end{array}$ & $\begin{array}{r}r 45 \cdot 3 \\
98 \cdot 5 \\
104 \cdot 4\end{array}$ & $\begin{array}{l}143 \cdot 8 \\
101 \cdot 1 \\
115 \cdot 8\end{array}$ & $\begin{array}{l}\text { I } 42 \cdot 3 \\
\text { IOI } 5 \\
\text { I I } 3 \cdot 4\end{array}$ & $\begin{array}{r}135 \cdot 9 \\
96 \cdot 7 \\
106 \cdot 9\end{array}$ & $\begin{array}{r}124 \cdot 2 \\
91 \cdot 3 \\
101 \cdot 7\end{array}$ & $\begin{array}{r}117 \cdot 7 \\
86 \cdot 4 \\
95 \cdot 4\end{array}$ & $\begin{array}{r}\text { II } 3.4 \\
82.4 \\
85.9\end{array}$ & $\begin{array}{l}99 \cdot 7 \\
67 \cdot 7 \\
79 \cdot 2\end{array}$ & $\begin{array}{l}87 \cdot 1 \\
57 \cdot 9 \\
69 \cdot 5\end{array}$ \\
\hline Inorganic $\mathbf{P}$ & $\begin{array}{l}\text { Control } \\
\text { Control }+\mathrm{P} \\
\text { Control }+\mathrm{B}\end{array}$ & $\begin{array}{l}48 \cdot 8 \\
64 \cdot 8 \\
40 \cdot 1\end{array}$ & $\begin{array}{l}47 \cdot 1 \\
77 \cdot 2 \\
44 \cdot 5\end{array}$ & $\begin{array}{l}43 \cdot 8 \\
7 I \cdot 4 \\
37 \cdot I\end{array}$ & $\begin{array}{l}43 \cdot 8 \\
70 \cdot 6 \\
36 \cdot 0\end{array}$ & $\begin{array}{l}42 \cdot 2 \\
64 \cdot 9 \\
35 \cdot 4\end{array}$ & $\begin{array}{l}42 \cdot 1 \\
67 \cdot 3 \\
36 \cdot 3\end{array}$ & $\begin{array}{l}43 \cdot 2 \\
65 \cdot 4 \\
37 \cdot 8\end{array}$ & $\begin{array}{l}42 \cdot 0 \\
65 \cdot 2 \\
35 \cdot 5\end{array}$ & $\begin{array}{l}41 \cdot 2 \\
63 \cdot 9 \\
34 \cdot 8\end{array}$ & $\begin{array}{l}4 \mathrm{I} \cdot 3 \\
63 \cdot 3 \\
34 \cdot 4\end{array}$ \\
\hline $\mathrm{CO}_{2}$ & $\begin{array}{l}\text { Control } \\
\text { Control + P } \\
\text { Control + B }\end{array}$ & $\begin{array}{r}50 \cdot 3 \\
109 \cdot 7 \\
131 \cdot 2\end{array}$ & $\begin{array}{r}41 \cdot 8 \\
117.7 \\
151.9\end{array}$ & $\begin{array}{r}36 \cdot 4 \\
99 \cdot 7 \\
\times 29 \cdot 6\end{array}$ & $\begin{array}{r}3 I \cdot 6 \\
8 I \cdot 9 \\
116 \cdot 5\end{array}$ & $\begin{array}{r}38 \cdot 6 \\
82 \cdot 1 \\
109 \cdot 3\end{array}$ & $\begin{array}{r}45.7 \\
95.0 \\
\times 10.6\end{array}$ & $\begin{array}{r}49^{\circ} 9 \\
104^{\circ} 6 \\
\text { I } 15.3\end{array}$ & $\begin{array}{r}41.0 \\
107.0 \\
125.8\end{array}$ & $\begin{array}{r}51 \cdot 6 \\
107 \cdot 7 \\
133 \cdot 0\end{array}$ & $54 \cdot 4$ \\
\hline
\end{tabular}

$\mathrm{P}$, incorporation of $3 \% \mathrm{Na}_{2} \mathrm{HPO}_{4}$ in the diet; $\mathrm{B}$, incorporation of $3 \%$ mixture (I:I) of $\mathrm{NaHCO}_{3}$ and $\mathrm{Na}_{2} \mathrm{CO}_{3}$ in the diet.

given this decline was significantly reduced $(P<0.00 \mathrm{I})$ when supplementary mineral buffers were given. The rumen $\mathrm{pH}$ values for the diet supplemented with bicarbonate buffer were on average higher $(P<0.05)$ than those which were obtained for the diet supplemented with $\mathrm{Na}_{2} \mathrm{HPO}_{4}$.

The VFA concentrations followed the usual trend, being low before feeding, increasing to peak levels $2-3 \mathrm{~h}$ after feeding, then decreasing to the original levels. The concentrations of VFA in the rumen were on average significantly higher $(P<0.01)$ when the control diet was given compared with the diets containing either buffer. The concentrations of VFA were lowest when the diet containing $\mathrm{Na}_{2} \mathrm{HPO}_{4}$ was given. As was to be expected, the concentrations of inorganic $P$ in the rumen were on average significantly higher when supplementary phosphate was given $(P<0.001)$ than when supplementary bicarbonate was given. The latter values were somewhat lower than those for the control diet. With both supplemented diets the rumen inorganic $P$ levels increased slightly after feeding. The concentrations of rumen $\mathrm{CO}_{2}$ were very significantly increased $(P<0.00 r)$ over those for the control diet when the buffers 
were given. They were particularly high, as expected, with the bicarbonate supplement.

The $\beta$ values are shown in Fig. I. With all three diets the values increased after feeding and returned to approximately the original values at the end of the sampling period. The $\beta$ values in the $\mathrm{pH}$ range $4^{-6}$ were on average significantly lower
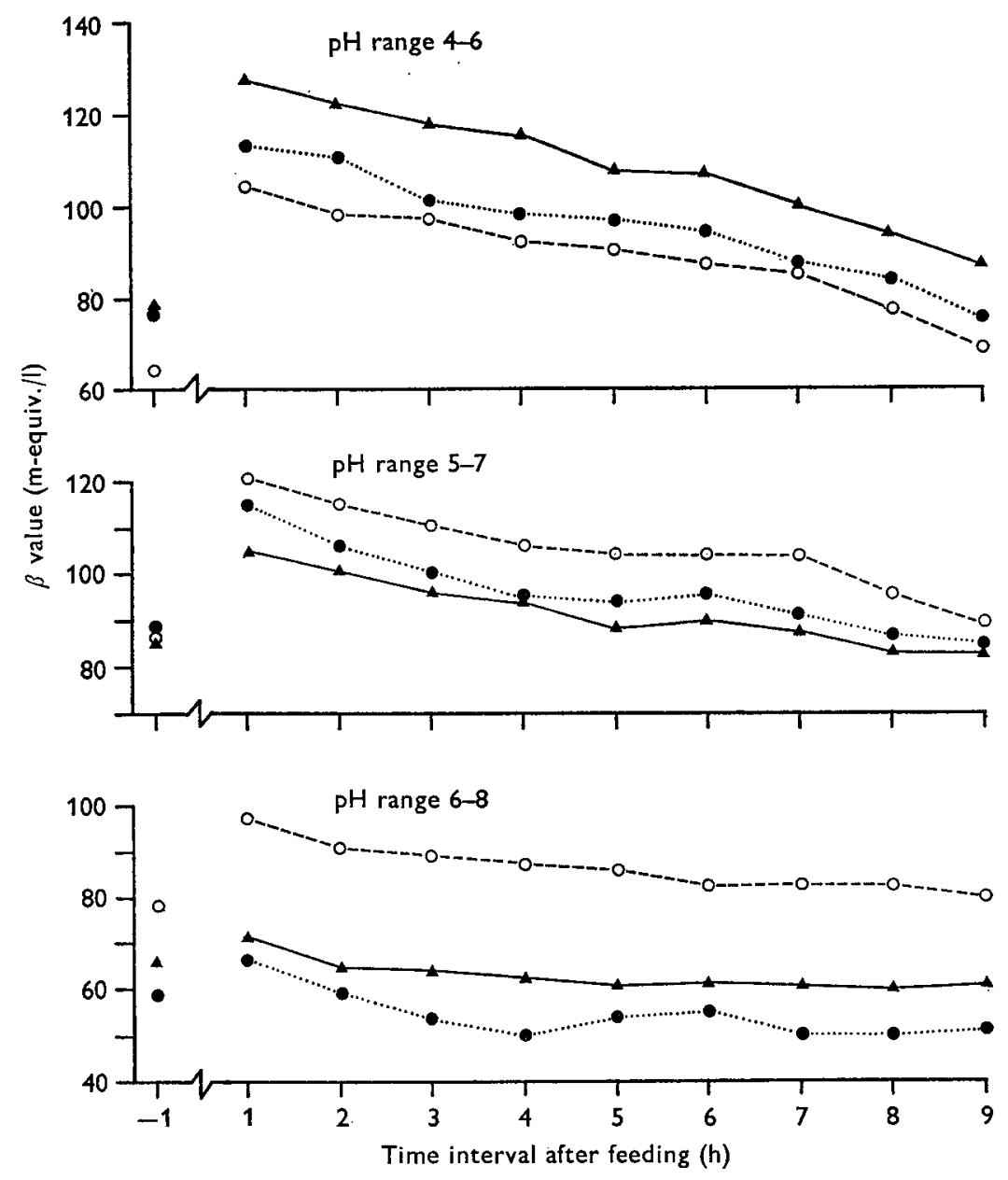

Fig. I. Buffering capacity $(\beta)$ values of the rumen fluid of sheep in the $\mathrm{pH}$ ranges $6-8,5-7$ and $4-6$ at intervals after feeding. $\Delta-\mathbf{\Delta}$, control diet; $\bigcirc-O$, control + phosphate; control + bicarbonate.

$(P<0.001)$ for the diets supplemented with buffers. In the $\mathrm{pH}$ range 6-8 the $\beta$ values obtained when supplementary phosphate was given were on average significantly higher $(P<0.001)$ than those for the control diet or the diet containing the supplementary bicarbonate mixture. For the latter diet the values were very uniform throughout the sampling period and were considerably lower than those for the control diet. With regard to the $\mathrm{pH}$ range $5^{-} 7$, the $\beta$ values were again highest $(P<0 \cdot 001)$ for 
the diet supplemented with $\mathrm{Na}_{2} \mathrm{HPO}_{4}$. Over this range the addition of the bicarbonate mixture did not produce much increase in the buffering value.

Table 2 summarizes the results for rumen cellulase activity. The amount of cellulose rendered soluble by the in vitro incubation, as a measure of cellulase activity in the rumen, was increased significantly $(P<0.01)$ by the addition of buffers to the diet. The $\mathrm{Na}_{2} \mathrm{HPO}_{4}$ buffer resulted in the greatest increase. No differences in rumen cellulase activity were observed at the two intervals after feeding.

\section{Table 2. Mean cellulase activity (\% total cellulose substrate digested) in the rumen fluid of two sheep at 4 or $9 h$ after feeding}

\begin{tabular}{|c|c|c|}
\hline Diet & $4 \mathrm{~h}$ & $9 \mathrm{~h}$ \\
\hline $\begin{array}{l}\text { Control } \\
\text { Control + P } \\
\text { Control + B }\end{array}$ & $\begin{array}{l}39 \cdot 9 \\
5 x \cdot 1 \\
45 \cdot 6\end{array}$ & $\begin{array}{l}38 \cdot 2 \\
47 \cdot 5 \\
43 \cdot 2\end{array}$ \\
\hline
\end{tabular}

$\mathrm{P}$, incorporation of $3 \% \mathrm{Na}_{2} \mathrm{HPO}_{4}$ in the diet; $\mathrm{B}$, incorporation of $3 \%$ mixture ( $\mathrm{I}: \mathrm{r}$ ) of $\mathrm{NaHCO}_{3}$ and $\mathrm{Na}_{2} \mathrm{CO}_{3}$ in the diet.

\section{DISCUSSION}

The effect of supplementary mineral buffers on rumen $\mathrm{pH}$, especially $2-3 \mathrm{~h}$ after feeding, was very marked. Differences between the maximum and minimum rumen $\mathrm{pH}$ values after giving the control diet were about $\mathrm{I} \cdot \mathrm{I} \mathrm{pH}$ units compared with $0.5 \mathrm{pH}$ unit after giving the diets supplemented with buffers. These results agree with the observations of Emery \& Brown (196r), Emery, Brown \& Thomas (r964), Nicholson et al. (1962) and Oltjen et al. (1962). It would appear on the other hand from the results of Johnson, Harbers \& Prescott (1959) and Lassiter, Hamdy \& Buranamanas (1963) that the incorporation of buffers in the drinking water does not result in changes in the rumen $\mathrm{pH}$. The increase in rumen $\mathrm{pH}$, which resulted from the addition of buffers in our experiments, reflected a decrease in the concentration of total VFA as well as an increase in the buffering value of the rumen fluid.

An important observation in the present work was the significant decrease in the concentrations of VFA throughout the day which accompanied the feeding of the diets containing supplementary buffers. Similar observations were made by Nicholson et al. (1962). On the other hand Raun et al. (1962) and Emery \& Brown (1961) reported that the addition of buffers to concentrate diets did not alter concentrations of total VFA, whereas Van Campen \& Matrone (I960) reported an increase in VFA concentrations when bicarbonates were added to a purified diet for sheep. In the latter work, however, the two experimental wethers used varied greatly in live weight $(2 \mathrm{I} \cdot 8$ and $56.8 \mathrm{~kg}$ ). The fact that the heavier animal, which was given the diet containing the supplementary mineral buffers, was also given a considerably greater allowance of food, may well account for the increased concentrations of rumen VFA observed in that animal. It is unlikely that supplementary mineral buffers would decrease VFA production in the rumen; on the contrary, they are expected to provide a more 
favourable environment for VFA production by controlling the rumen $\mathrm{pH}$. It is possible therefore that the decrease in VFA concentrations observed when these supplements are added reflects increased VFA absorption. In a recent study of carbonic anhydrase activity in the wall of the forestomachs of cows, Aafjes ( 1967 ) has postulated that when $\mathrm{CO}_{2}$ tension is high in the rumen some of it could be recycled into the rumen via the rumen villi as $\mathrm{HCO}_{3}^{-}$in exchange for VFA, thereby increasing the absorption rate of the VFA. Since in our work total rumen $\mathrm{CO}_{2}$ concentrations were measured, it was not possible to detect variations in $\mathrm{HCO}_{3}^{-}$concentrations. Our results support the hypothesis of Aafjes ( $x_{967}$ ). The rumen total $\mathrm{CO}_{2}$ concentrations were markedly increased by the addition of buffers and the bicarbonate buffer resulted in the greatest increase. Both buffers contributed to the maintenance of a higher rumen $\mathrm{pH}$ while at the same time lower VFA concentrations were observed, resulting presumably from their increased absorption.

Both the phosphate and bicarbonate buffers significantly increased rumen cellulase activity as measured in vitro. Lassiter \& Cook (1961, 1963) and Lassiter et al. (1962) also found that the addition of bicarbonate to the drinking water caused an increase in the digestibility of crude fibre. Lassiter \& Barnhill (196r) and Hall, Baxter \& Hobbs ( $196 \mathrm{I}$ ) observed an increase in cellulose digestibility in vitro when supplementary phosphates were added to the substrate. Thus the increase in cellulolytic activity would seem to reflect the higher rumen $\mathrm{pH}$ which prevailed after supplementation with mineral buffers. Regardless of diet, cellulase activity showed no response to time after feeding. This is important since it suggests that the depression in rumen cellulase activity which accompanied low rumen $\mathrm{pH}$ when animals were given our type of ration is not of a temporary nature, i.e. cellulase activity is not elevated when the rumen $\mathrm{pH}$ subsequently increases with time after feeding. The effect is probably a more permanent one and results in a reduction of the activity or number of the rumen cellulolytic bacteria.

There were no significant variations in the concentrations of rumen inorganic $P$ with time after feeding (Emmanuel et al. 1969). The fact that the lowest levels were observed for the diet supplemented with bicarbonate buffers may have resulted from a decreasing solubility of $\mathrm{P}$ with the higher rumen $\mathrm{pH}$. With regard to the $\beta$ values, there was again (Emmanuel et al. 1969) a significant correlation $(r=0.96)$ between rumen VFA concentrations and $\beta$ values in the $\mathrm{pH}$ range $4-6$. The lowest concentrations of rumen VFA and the lowest $\beta$ values were observed when the diet containing $\mathrm{Na}_{2} \mathrm{HPO}_{4}$ was given.

In the $\mathrm{pH}$ range $6-8$ there was a good correlation $\left(r=0^{\circ} 94\right)$ between the levels of inorganic $\mathrm{P}$ in the rumen and the very high $\beta$ values for the diet supplemented with $\mathrm{Na}_{2} \mathrm{HPO}_{4}$. The $\beta$ values were lowest for the diet containing the bicarbonate buffer, as were the levels of inorganic $P$.

The relationship between the $\beta$ values in the $\mathrm{pH}$ range $5-7$ and dietary treatment is of particular interest. Fig. I shows that the diet containing $\mathrm{Na}_{2} \mathrm{HPO}_{4}$ gave the highest $\beta$ values. On the other hand, the diet containing the bicarbonate buffer resulted in a higher rumen $\mathrm{pH}$ while at the same time the concentrations of VFA were considerably higher. It seemed contradictory that a higher rumen $\mathrm{pH}$ should be 
associated with increased concentrations of VFA, and in order to clarify this point the $\beta$ values were calculated in each instance for one unit changes in rumen $\mathrm{pH}$. The results obtained are illustrated in Fig. 2. It will be noted that the $\beta$ values in the $\mathrm{pH}$ ranges $4^{-5}$ and $5^{-6}$ were almost identical when the control diet was given. This is to be expected since the $\mathrm{pK}$ value of VFA is about 4.85 . When the diets containing the buffers were given, the $\beta$ values in the $\mathrm{pH}$ range $4-5$ were greatly reduced as a result of the lower VFA concentrations. However, this decrease in $\beta$ values did not occur over the $\mathrm{pH}$ range $5-6$. Indeed, on the contrary, it will be noted that the $\beta$ values in

(a)

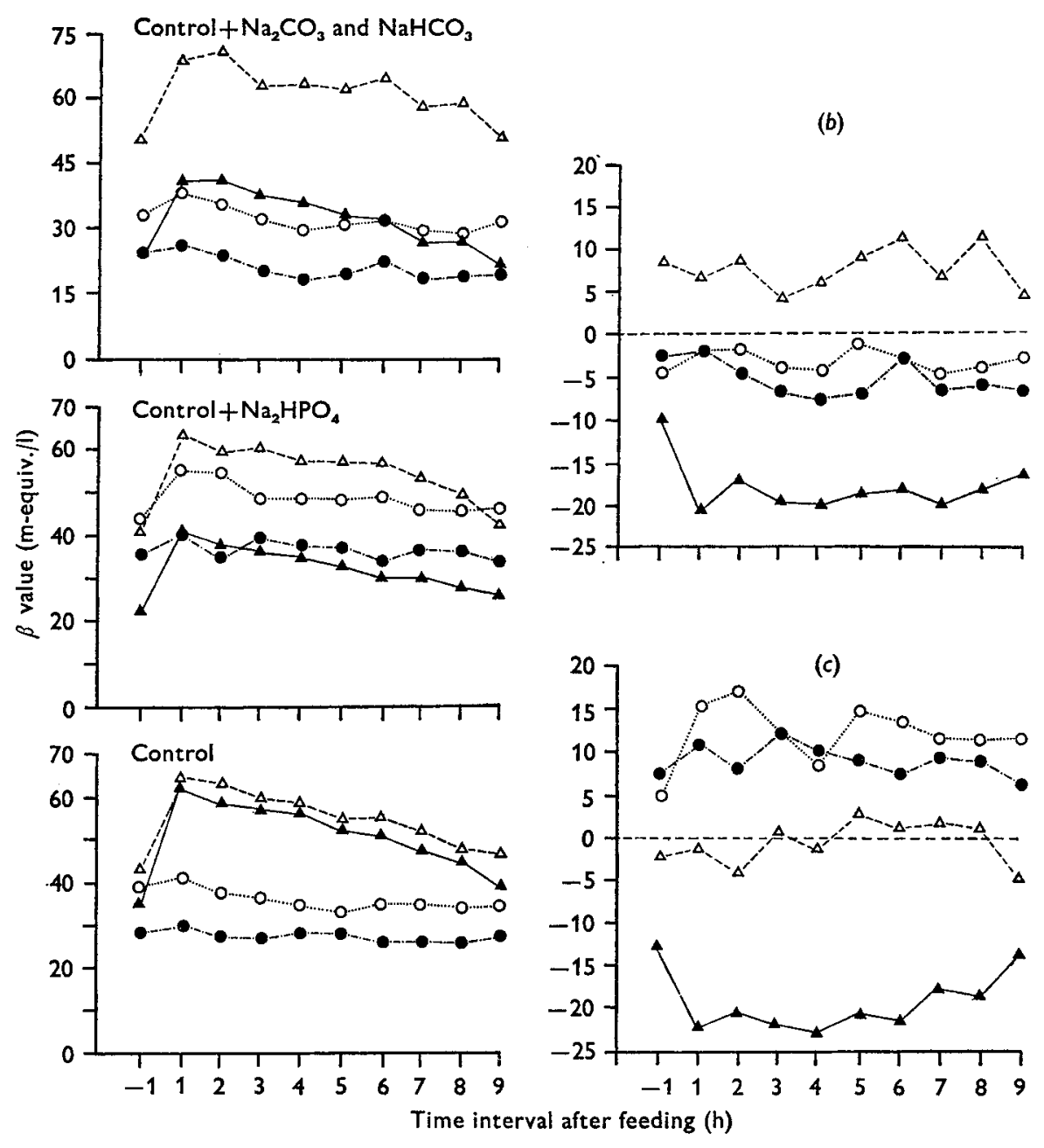

Fig. 2. Buffering capacity $(\beta)$ values of the rumen fluid of sheep given the control diet or the control diet supplemented with $\mathrm{NaHCO}_{3}$ and $\mathrm{Na}_{2} \mathrm{CO}_{3}$ or the control diet supplemented with $\mathrm{Na}_{2} \mathrm{HPO}_{4}:(a)$ comparison of $\beta$ values for each diet in the $\mathrm{pH}$ ranges $4-5,5-6,6-7$ and $7-8$; (b) difference in the $\beta$ values between the control diet and the diet supplemented with $\mathrm{NaHCO}_{3}$ and $\mathrm{Na}_{2} \mathrm{CO}_{3} ;(c)$ difference between the $\beta$ values for the control diet and the diet supplemented with $\mathrm{Na}_{2} \mathrm{HPO}_{4}$. $\triangle, \mathrm{pH}_{4-5} ; \triangle, \mathrm{pH}{ }_{5}-6 ; \mathrm{O}, \mathrm{pH} 6-7 ; \bullet, \mathrm{pH} 7-8$. 
the $\mathrm{pH}$ range $5^{-6}$ were increased (Fig. $2 a$ ) in the presence of the bicarbonate buffer. When the phosphate buffer was given, the $\beta$ values in the $\mathrm{pH}$ range $6-7$ and to a lesser extent in the range 7-8 were increased. The bicarbonate buffer on the other hand did not give a response in the $\mathrm{pH}$ range 6-7. Thus there appears to be a considerable overlap between the effectiveness of the mineral supplements if the $\beta$ values for each buffer in the range 5-7 are compared. Fig. $2 b$ and $c$, in which the $\beta$ values for the control diets are subtracted from the corresponding values for the supplemented diet, shows the magnitude of these differences. We may say, therefore, that while both buffers were effective in regulating $\mathrm{pH}$ the bicarbonate buffer was particularly so in the $\mathrm{pH}$ range $5^{-6}$ and the phosphate buffer in the $\mathrm{pH}$ range $6-7$.

We thank Mr D. Conniffe of the Statistics Department for the statistical analysis of the results. The authors are indebted to Seán P. Hopkins for his valuable technical assistance.

\section{REFERENCES}

Aafjes, J. H. (1967). Br. vet. F. 123, 252.

Balch, D. A. \& Rowland, S. J. (1957). Br. F. Nutr. 11, 288.

Emery, R. S. \& Brown, L. D. (196r). F. Dairy Sci. 44, 1899.

Emery, R. S., Brown, L. D. \& Thomas, J. W. (1964). F. Dairy Sci. 47, I325.

Emmanuel, B., Lawlor, M. J. \& McAleese, D. M. (I969). Br. F. Nutr. 23, 805.

Hall, O. G., Baxter, H. D. \& Hobbs, C. S. (196r). F. Anim. Sci. 20, 8I7.

Halliwell, G. (1957). F. gen. Microbiol. 17, r53.

Johnson, C. E., Harbers, L. H. \& Prescott, J. M. (1959). J. Anim. Sci. r8, 599.

Lassiter, J. W. \& Barnhill, H. D. (1961). F. Anim. Sci. 20, 395.

Lassiter, J. W. \& Cook, M. K. (1961). F. Anim. Sci. 20, 940.

Lassiter, J. W. \& Cook, M. K. (1963). F. Anim. Sci. 22, 384.

Lassiter, J. W., Cullison, A. E. \& Warren, E. P. (1962). F. Anim. Sci. 21, 385.

Lassiter, J. W., Hamdy, M. K. \& Buranamanas, P. (I963). F. Anim. Sci. 22, 335.

Lawlor, M. J., Giesecke, D. \& Walser-Kärst, K. (r966). Br. F. Nutr. 20, 373 .

Nicholson, J. W. G. \& Cunningham, H. M. (I96I). Can. F. Anim. Sci. 41, 134.

Nicholson, J. W. G., Cunningham, H. M. \& Friend, D. W. (1962). Can. F. Anim. Sci. 42, 75.

Nicholson, J. W. G., Cunningham, H. M. \& Friend, D. W. (1963). Can. F. Anim. Sci. 43, 309.

Nicholson, J. W. G., Loosli, J. K. \& Warner, R. G. (1960). F. Anim. Sci. r9, 1071.

Oltjen, R. R., Sirny, R. J. \& Tillman, A. D. (1962). F. Nutr. 77, 269.

Raun, N. S., Burroughs, W. \& Woods, W. R. (1962). F. Anim. Sci. 21, 838 ,

Reid, R. L., Hogan, J. P. \& Briggs, P. K. (I957). Aust. F. agric. Res. 8, 691.

Van Campen, D. R. \& Matrone, G. (1960). F. Nutr. 72, 277. 